\title{
ISOLASI BAKTERIPENGHASIL ANTIBIOTIKA DARI CAIRAN KANTUNG TUMBUHAN KANTONG SEMAR (Nepenthes spp.) CAGAR ALAM LEMBAH HARAU SUMATERA BARAT
}

\author{
Yosmed Hidayat* \\ ${ }^{1}$ Program Studi Pendidikan Biologi STKIP PGRI Sumatera Barat \\ Jl. Gunung Pangilun Padang Telp. 0751-70537310 \\ (Diterima 17 Maret 2015, disetuji 12 April 2015)
}

\begin{abstract}
Exploration of antibiotic-producing micro organisms continue to get good anti biotic-producing isolates. Many producers of anti biotic substances have been isolated, but a small portion of them are proven to be beneficial to both, especially in the health field. Some antibiotic-producing micro organisms found in places with diverse condition sone of which isa liquid Nepenthes spp. The fluidin the saccontaining plant Nepenthes chemical compounds, acidic and capable of digesting insects that go into the bag. This of course affects the fluid sacas a growing medium for bacteria. Some bacteria are capable of producing antibiotics to the specific need sof the bacteria to survive unfavorable conditions. Harau Valley Nature Reserveis one ofthe habitats where the growing Nepen the sin West Sumatra. However, no studies have discussed the presence of antibiotic-producing bacteria in the fluid sacin this area. Sampling sac fluid of Nepenthes spp., conducted by purposive sampling method. Antibiotic testing of bacterial isolates was conducted using paper disc. From the results of bacterial isolation was obtained 137 bacterial isolates were scattered in four different type sof fluid sac Nepenthes including N. ampullaria, N.gracilis, N.eustacya and N. albomarginata. Antibiotic testing ten isolates were isolated from the fluid sac Nepenthes spp., generally indicates the ability of antibiotic stoutest the bacteria E.coli and $S$. aureus. Isolates KS.4-3 havethe best antibiotic against E.coli with inhibition zone diameter of $29.5 \mathrm{~mm}$ and isolatees reached KS. 1-7 against the bacteria S.aureus with in hibition zone diameter of $26.3 \mathrm{~mm}$ reach.
\end{abstract}

Keywords : Isolation, Antibiotics, Nepenthes, Kantung Semar

\begin{abstract}
ABSTRAK
Eksplorasi mikro organisme penghasil antibiotika terus dilakukan untuk mendapatkan isolat penghasil antibiotika yang baik. Banyak substansi penghasil antibiotika yang telah diisolasi, namun sebagian kecil diantaranya yang terbukti bermanfaat dengan baik terutama dalam bidang kesehatan. Beberapa mikroorganisme penghasil antibiotika ditemukan pada tempat dengan kondisi yang beragam salah satunya adalah cairan kantong semar atau Nephentes spp. Cairan pada kantung tumbuhan Nepenthes mengandung senyawa-senyawa kimia, bersifat asam dan mampu mencerna serangga-serangga yang masuk ke dalam

*Penulis korespondensi : Yosmed Hidayat. Prodi Pendidikan Biologi STKIP PGRI Sumatera Barat
\end{abstract}


kantung. Kondisi ini tentunya mempengaruhi cairan kantung sebagai media tumbuh bagi bakteri. Beberapa bakteri mampu menghasilkan antibiotika tertentu sesuai dengan kebutuhan bakteri untuk bertahan dari kondisi yang tidak menguntungkan. Cagar Alam Lembah Harau merupakan salah satu habitat tempat tumbuh Nepenthes di Sumatera Barat. Namun belum ada penelitian yang membahas keberadaan bakteri penghasil antibiotika dalam cairan kantung di daerah ini. Pengambilan sampel cairan kantung Nepenthes spp.,dilakukan dengan metoda purposive sampling. Pengujian antibiotika isolate hasil isolasi dilakukan dengan metode kertas cakram. Dari hasil isolasi bakteri diperoleh 137 isolat bakteri yang tersebar dalam 4 jenis cairan kantung Nepenthes diantaranya $N$. ampullaria, $N$. gracilis, $N$ eustacya dan $N$. albomarginata. Pengujian antibiotika 10 isolat yang diisolasi dari cairan kantung Nepenthes spp., secara umum menunjukkan kemampuan antibiotika terhadap bakteri uji E. coli dan S.aureus. Isolat KS.4-3 memiliki antibiotika terbaik terhadap E. coli dengan diameter zona hambat mencapai 29,5 $\mathrm{mm}$ dan isolat KS. 1-7 terhadap bakteri S. aureus dengan diameter zona hambat mencapai $26,3 \mathrm{~mm}$.

Katakunci : Isolasi, Antibiotika, Nepenthes, Kantung Semar

\section{PENDAHULUAN}

Eksplorasi mikroorganisme penghasil antibiotika hingga saat ini masih terus dilakukan untuk mendapatkan isolat-isolat penghasil antibiotika yang baik. Hingga saat ini sudah banyak substansi antibiotika yang diisolasi, namun baru sedikit diantaranya yang terbukti bermanfaatdengan baik terutama dalam bidang kesehatan (Pelczar \& Chan, 1998). Beberapa mikroorganisme penghasil antibiotikadapat ditemukanpada daerah dengan kondisi yang beragam seperti daerah dengan suhu tinggi, suhu rendah, laut bagian dalam, padang pasir, lapisan es, sumber air panas dan minyak (Crueger and Crueger,1984).Bakteri penghasil antibiotika juga berhasil diperoleh dari berbagai jenis tanaman, salah satunya adalah kantong semar atauNephentes spp.,(Sulistianingsih, 2008).

Sulistianingsih (2008) melaporkan dari tiga jenis isolat bakteri hasil isolasi cairan kantung Nepenthesampullaria,diperoleh bakteri dengan koloni bewarna merah, ungu dan putih yang menunjukkan adanya aktivitas antibiotika terhadap Bacillus subtilis, dan Escerichia coli. Namun masih sedikit informasi yang 
menjelaskan potensi bakteri dalam cairan kantung, begitu juga dengan karakter dan kemampuannya dalam memproduksi antibiotika.

Kantong semar merupakan tumbuhan karnivora karena memiliki cairan kantung mencernanya menjadi salah satu sumber protein untuk memenuhi kebutuhan hidupnya (Chen et al., 2005). Cairan kantung bersifat asam dan mengandung senyawa-senyawa seperti kinin, plumbagin, nepentesin dan lainya. Namun cairan kantung tidak membunuh semua organisme yang memasuki perangkap, setidaknya beberapa organismeseperti bakteri dapat bertahan dan berkembang biak dalam perangkap kantung (Adlassniget al., 2011).Analisis komunitas bakteri dalam cairan kantung beberapa tanaman kantong semar yang dikoleksi di daerah Kalimantan Timur, Bangka dan Yogyakarta, diperoleh isolat bakteri dengan jumlah yang relatif tinggi. Hal ini menggambarkan bahwa cairan kantung merupakan suatu reservoiryang baik bagi kehidupan bakteri (Yogiara, 2004).

Pulau Sumatera diketahui memiliki 29 jenis tanaman kantong semar tersebar padaberbagai daerah di pulau ini (Mansur, 2006). Keberagaman tanaman kantong semar yang hidup di berbagai darah tersebut, tentunya memberikan kemungkinan terdapatnya berbagai jenis bakteri dengan kemampuan yang beragam, sebagai pengahasil antibiotika.Cagar alam Lembah Harau merupakan salah satu habitat tempat tumbuhnya berbagai jenis tanaman kantong semar di daerah Sumatera Barat (Kurniawati, 2010). Namun belum ada penelitian yang membahas keberadaan bakteri penghasil antibiotika yang terdapat dalam cairan kantung tumbuhan kantung semar di daerah ini.Berdasarkan uraian di atas, maka dilakukan penelitian terhadap isolat bakteri penghasil antibiotika yang terdapat 
dalam cairan kantung tumbuhan kantong semar yang berada di hutan Bukik Rangkakcagar alam Lembah Harau Sumatera Barat serta karakter dan potensinya sebagai penghasil antibiotika.

\section{METODA PENELITIAN}

Penelitian ini dilaksanakan pada bulan Oktober 2013 sampai selesai. Sampel cairan kantung tumbuhan kantong semar (Nepenthes spp.) dikoleksi di hutan Bukit Rangkak Cagar Alam Lembah Harau Sumatera Barat. Untuk kegiatan laboratorium dilaksanakan di Laboratorium Riset MikrobiologiUniversitas Andalas dan Universitas Negeri Padang. Pengambilan sampel cairan kantung semar dilakukan berdasarkanmetoda purposif sampling. Pengambilan sampel cairan Nepenthes spp., dilakukan dengan cara penuangan lansung cairan kantung ke dalam botol sampel hingga tetes terakhir. Proses isolasi bakteri cairan padatiap kantung menggunakan medium Nutrien Agar dan diinkubasi pada suhu ruang selama 24-48 jam. Proses ini dilenjutkan dengan pemurnian isolat bakteri dan pengamatan morfologi koloni bakteri.

Produksi metabolit antibiotika oleh bakteri hasil isolasi dilakukan dengan cara menumbuhkan dalam medium produksi antimikroba. Biakan murni bakteri umur dua hari (hasil isolasi cairan kantung) diambil sebanyak 1 ose dan diinokulasikan ke dalam $25 \mathrm{~mL}$ medium NB untuk tiap sampel bakteri hasil isolasi (pre culture) dan diinkubasi selama 24 jam. Kemudian dari pre culture diambil sebanyak $10 \mathrm{ml}$ isolat dan dipindahkan kedalam tabung erlemeyer yang berisi $100 \mathrm{ml}$ medium produksi antimikroba (main culture) dan difermentasi selama 3 haridi ataspengocok orbital dengan kecepatan $150 \mathrm{rpm}$.Cairan hasil fermentasi dimasukkan ke tabung-tabung Eppendorf 1,5 mL, laludisentrifugasi 
pada kecepatan $10.000 \mathrm{rpm}$ selama 1 menit. Supernatannya dipindahkan ke tabungbaru, sedangkan endapan sel bakteri dibuang.

Untuk pengujian kemampuan antibiotika isolat hasil isolasi, mengacu kepada metode kertas cakram. Masing-masing $1 \mathrm{~mL}$ suspensi $\left(10^{-7} \mathrm{sel} / \mathrm{ml}\right)$ bakteri E. coli dan $S$. aureus ditebarkan pada permukaan $15 \mathrm{~mL}$ medium NA dalam cawan petri (spread plate). Tempatkan kertas cakram yang telah direndam dengan supernatan bakteri hasil isolasi di atas medium NA. Proses inkubasi dilakukan pada suhu $37^{\circ} \mathrm{C}$ (sesuai dengan suhu optimum bakteri uji) selama 24 jam. Bakteri yang memiliki kemampuan dalam menghasilkan senyawa antibiotika menunjukkan adanya zona bening (zona hambatan) di sekitar koloni bakteri uji. Kemudian dilakukan pengukuran diameter daerah bebas bakteri (zona bening) yang terbentuk di sekitar kertas cakram.

\section{HASIL DAN PEMBAHASAN}

\section{A. Isolasi Bakteri Cairan Kantung Nepenthes spp.}

Proses isolasi bakteri dilakukan pada sampel cairan kantung dari 4 jenis tumbuhan Nepenthes yang dikoleksi di lapangan diantaranya N. ampullaria, N. gracilis, N. eustachya dan $N$. albomarginata. Dari hasil pemurnian diperoleh 137 biakan koloni murni bakteri yang tersebar dalam 36 cairan kantung yang dikoleksi.

Tabel 1. Jumlah isolat bakteri masing-masing cairan kantung

\begin{tabular}{c|l|c}
\hline No & Sumber Isolat & Isolat \\
\hline 1. & N. ampullaria & 36 \\
2. & N. gracilis & 36 \\
3. & N. eustachya & 35 \\
4. & N. albomarginata & 30 \\
\hline \multicolumn{2}{l}{ Total } & 137 \\
\hline
\end{tabular}




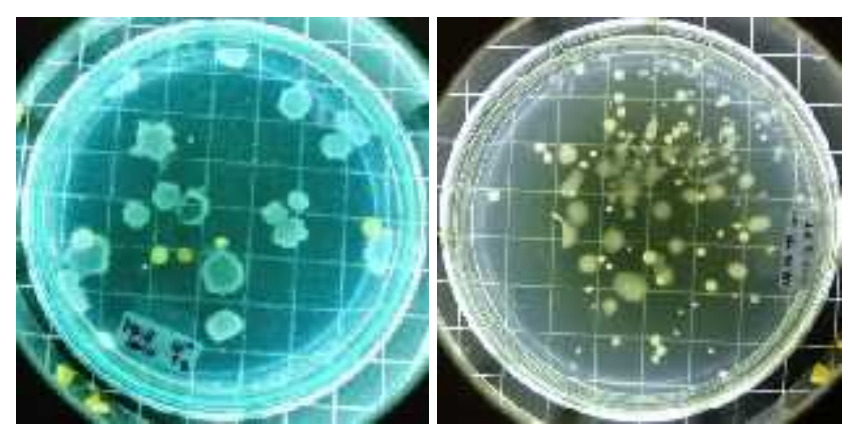

Gambar 1. Contoh biakan bakteri dari cairan kantung Nepenthes

Tabel 1 menunjukkan bahwa masing-masingNepenthesmengandung jumlah isolat yang relatif sama. Adanya isolat bakteri pada cairan kantung Nepenthes memperlihatkan bahwa cairan kantung dapat digunakan oleh isolat bakteri untuk kehidupannya. Menurut Yogiara (2004) total bakteri yang relatif tinggi menggambarkan bahwa cairan kantung semar merupakan suatu reservoir bagi kehidupan.

Banyak faktor yang dapat mempengaruhi jumlah isolat bakteri pada cairan kantung, diantaranya ketersediaan nutrisi dalam cairan kantung. Jenis serangga yang terperangkap serta adanya organisme lain yang bersifat predator yang dapat membantu proses penguraian, sehingga menambah kekayaan nutrisi dalam cairan kantung. Menurut Peterson et al.,(2008), jenis serangga yang terperangkap dalam cairan kantung dapat mempengaruhi jenis bakteri yang mampu berkembang dalam cairan kantung Nepenthes serta hadirnya organisme yang bersifat predator. Selain itu keberadaan isolat bakteri dalam cairan kantung dapat dipengaruhioleh kondisi dalam cairan kantung tumbuhan itu sendiri. Kantung mampu mensekresikan beberapa senyawa ke dalam cairan yang dapat membantu merombak atau mendegradasi serangga-serangga yang menjadi substrat bagi tumbuhan ini seperti fosfat, kalium, dan unsur senyawa organik lainya. Kondisi ini tentunya mempengaruhi cairan kantung sebagai media tumbuh bagi bakteri. 


\section{B. Uji Antibiotika Beberapa Isolat Bakteri}

Pengujian dari 10 isolat yang diambil secara acak (Tabel 3) dari isolat hasil isolasi menunjukkan secara umum isolat bakteri hasil isolasi cairan kantung dapat menghasilkan antibiotika yang mampu menghambat pertumbuhan bakteri uji yaitu E. coli dan $S$. aureus. Adanya antibiotika yang dihasilkan isolat ditandai dengan terdapatnya daerah yang tidak ditumbuhi bakteri uji (Gambar 1). Menurut Madiganet al.,(2012) selama inkubasisupernatan bakteri berdifusi dari kertas cakram ke media agar, membangun gradien yang menunjukkan kemampuan menghambat dari subtrat yang diuji. Kepekaan mikroba uji ditandai dengan besar diameter zona jernih yang terbentuk. Makin besar zona jernih makin peka mikroba uji terhadap senyawa antimikroba tersebut (Kumala et al., 2006).

Tabel 2. Uji antibiotika isolat bakteri hasil isolasi cairan kantung terhadap bakteri E. coli dan $S$. aureus

\begin{tabular}{|c|c|c|c|}
\hline \multirow{2}{*}{ No } & \multirow{2}{*}{ Bakteri Hasil Isolasi } & \multicolumn{2}{|c|}{ Diameter zona hambat (mm) } \\
\hline & & E.coli & S.aureus \\
\hline 1 & KS.4-1 & 9,5 & 11,6 \\
\hline 2 & KS.2-8 & 9,2 & 8,1 \\
\hline 3 & KS.1-22 & 7,9 & 8,4 \\
\hline 4 & KS.1-10 & 14,1 & 9,5 \\
\hline 5 & KS.4-3 & 29,5 & 13,4 \\
\hline 6 & KS.2-9 & 17,1 & 8,6 \\
\hline 7 & KS.1-7 & 27,3 & 26,3 \\
\hline 8 & KS.2-14 & 6,5 & 12,0 \\
\hline 9 & KS.2-20 & 6,4 & 7,7 \\
\hline 10 & KS.3-9 & 23,9 & 19,6 \\
\hline
\end{tabular}




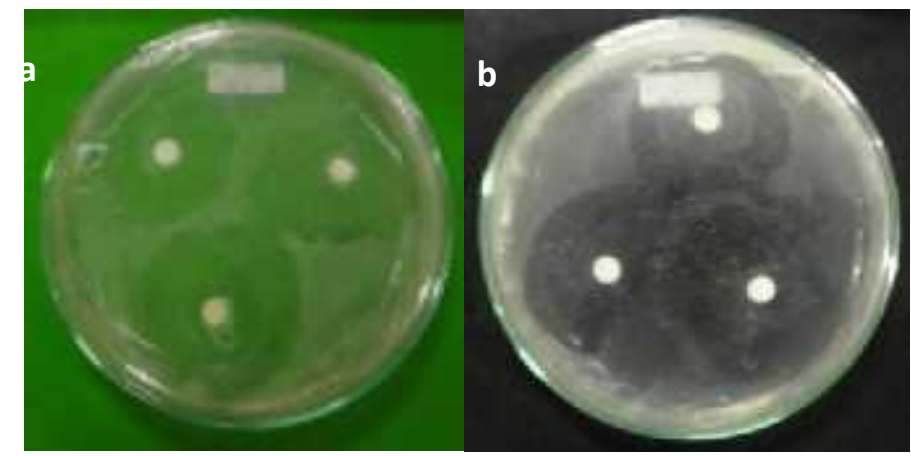

Gambar 3. Hasil pengujian aktifitas antibiotika. a) Uji isolatKS.4-3 terhadap bakteri E. coli, b) Uji isolat KS.1-7 terhadap bakteri S. aureus.

Hasil uji antibiotika isolat hasil isolasi menunjukkan bahwa isolat memiliki kemampuan antibiotikaa yang tinggi terhadap bakteri $E$. coli dan $S$. aureusdiantaranya isolat KS.4-3, KS.1-7, KS.3-9 terhadap bakteri E. coli dan KS.1-7, KS.3-9 terhadap bakteri S. aureus. Untuk daya hambat tertinggi terhadap E. coli dimiliki isolat KS.4-3, dengan diameter zona bening mencapai 29,5 mm. Sedangkan terhadap bakteriS. aureus daya hambat tertinggi dimiliki isolat KS.1-7 dengan diameter zona mencapai $26,3 \mathrm{~mm}$.

Perbedaan kemampuan bakteri dalam menghambat pertumbuhan bakteri uji kemungkinan berkaitan dengan jenis antibiotika yang dihasilkan. Beberapa bakteri mampu menghasilkan antibiotika tertentu sesuai dengan kebutuhan selnya. Selain itu setiap jenis antibiotika yang dihasilkan memiliki kemampuan dan proses yang berbeda pula dalam menghambat bakteri uji yang digunakan. Menurut Pelczar and Chan (1988) beberapa bakteri mampu menghasilkan senyawa yang bersifat bakterisida atau bakteriostatis seperti streptomisin, tetrasiklin, kolistin dan lainnya. Volk and Wheeler (1993) juga menyatakan bahwa senyawa antibiotika yang dihasilkan dapat menghambat sintesis dinding sel, merusak membran sitoplasma, menghambat biosintesis protein dan menghambat 
sintesis asam nukleat.Selain itu, jenis bakteri uji yang digunakan juga dapat mempengaruhi kemampuan isolat hasil isolasi dalam menghambat pertumbuhan bakteri uji. Bakteri Gram negatif memiliki ketahanan yang lebih baik dibandingkan dengan bakteri Gram positif terhadap senyawa antimikroba karena bakteri Gram negatif memiliki struktur sel yang lebih kompleks bila dibandingkan bakteri Gram positif. Menurut Zuhudet al. (2001) bakteri Gram negatif memiliki ketahanan yang lebih baik terhadap senyawa antimikroba bila dibandingkan dengan bakteri Gram positif. Selain itu, Pelczar and Chan (1986) menyatakan bahwa struktur dinding sel bakteri Gram-positif lebih sederhana sehingga memudahkan senyawa antimikroba untuk masuk kedalam sel dan menemukan sasaran untuk bekerja.

Besarnya diameter zona bening yang dimiliki isolat bakteri hasil isolasi terhadap pertumbuhan bakteri tertentu menunjukkan bahwa masing-masing isolat bakteri memiliki kepekaan antibiotika yang berbeda terhadap bakteri uji yang digunakan. Isolat KS.4-3 cukup baik dalam menghambat pertumbuhan E. coli, namun memiliki kemampuan yang tergolong rendah dalam menghambat pertumbuhan $S$. aureus dengan diameter zona bening hanya mencapai $13,4 \mathrm{~mm}$. Menurut Pratiwi (2008) beberapa bakteri memiliki spektrum antibiotika yang sempit dimana hanya mampu menghambat pertumbuhan golongan bakteri tertentu saja.

Berbeda dengan isolat KS.4-3, isolat bakteri KS.1-7 memiliki daya hambat yang tergolong tinggi untuk kedua jenis bakteri uji yang digunakan. Isolat KS.1-7 menghasilkan diameter zona bening mencapai $27,3 \mathrm{~mm}$ terhadap E.coli dan 26,3 mm terhadap S. aureus. Hasil ini menunjukkan bahwa isolat KS.1-7 menghasilkan 
antibiotika dengan spektrum yang baik karena mampu menghambat kedua jenis bakteri uji dengan diameter yang tergolong tinggi. Menurut Pelczar and Chan (1986)antibiotika dapat dikatakan memiliki spektrum yang luas bila mampu menghambat atau membunuh bakteri dari golongan Gram positif maupun Gram negatif. Kemampuan ini tentunya sangat diharapkan karena antibiotika yang dihasilkan KS.1-7 memberikan peluang yang lebih besar dalam penghambatan berbagai bakteri lain yang tidak diinginkan. Sesuai dengan pernyataan Pelczar and Chan (1988) salah satu sifat antibiotikaa yang ideal adalah mampu menghambat banyak mikro-organisme patogen. Selain itu Kos et al., (2011) menyatakan bahwa aktivitas bakteriocinogenik sebagai bagian aktivitas dari antimikroba merupakan aspek fungsional penting yang dituntut untuk menghambat mikroorganisme yang tidak diinginkan.

\section{KESIMPULAN}

Isolat bakteri hasil isolasi cairan kantung Nepenthes yang dikoleksi disekitar Cagar Alam Lembah Harau Sumatera Barat secara umum menunjukkan aktifitas antibiotikanya terhadap bakteri uji. Kemampuan antibiotika tertinggi dihasilkan isolat KS.4-3 terhadap bakteri E. colidengan diamter zona hambat mencapai 29,5 mm dan isolat KS.1-7 terhadap bakteri S. aureus dengan diamter zona hambat mencapai $26,3 \mathrm{~mm}$.

\section{UCAPAN TERIMAKASIH}

Terimakasih kepada seluruh pihak yang telah terlibat memberikan dukungan moril maupun materil sehingga penelitian ini dapat terlaksana dengan baik 


\section{DAFTAR PUSTAKA}

Adlassnig, W., M. Peroutka and T. Lendl.2011. Traps of carnivorous pitcher plants as a habitat: composition of the fluid, biodiversity and mutualistic activities. J. Annals of Botany. 107; 181-194.

Buch, Franziska., M. Rott, S. Rottloff, C. Paetz, I. Hilke,M. Raessler and A. Mitho. 2013. Secreted pitfall-trap fluid of carnivorous Nepenthes plants is unsuitablefor microbial growth. Annals of Botany 111: 375-383.

Chen, Y., M. Qi, W. Lu, W. Dong, S. Wang and Z. Zheng. 2005. Carnivorus plant nepenthes.Roskilde University.

Crueger, W and A. Crueger. 1994. Biotechnology: A Textboook of Industrial Microbiology. Science Tech, Inc. USA.

Kurniawati, Reza. 2010. Serangga yang terdapat pada kantong N. albomarginata T.Lobb ex Lindl dan N. eustachya Miq. di kawasan Cagar Alam Lembah Harau Kabupaten Limapuluh Kota. Skripsi. Univ. Andalas

Kos, B., J. Beganović, L. Jurašić, M. Švađumović, A.L. Pavunc, K. Uroić and J. Šušković. 2011. Colculture inducible bacteriocin biosynthesis of different probiotic strains by dairy starter culture Lactococcus lactis. Dairy starter culture Lactococcus lactis. Mljekarstvo. 61(4); 273-282.

Madigan, M.T., J.M. Martinko, D.A. Stahl and D.P. Clark. 2012. Brock biology of microorganisms, 13th ed. Pearson Education, Inc. San Francisco.

Mansur, M. 2006. Nepenthes, kantong semar yang unik. Penebar Swadaya. Jakarta.

Pelczar, M.J. and E.C.S. Chan. 1988. Dasar-dasar Mikrobiologi. Univ. Indonesia.Jakarta.

Peterson C. N., S. Day,B.E. Wolfe, A. M. Ellison,R. Kolter and A. Pringle. 2008. A keystone predator controls bacterial diversity in thepitcher-plant (Sarracenia purpurea) microecosystem. Environmental Microbiology 10(9); 2257-2266.

Prescott, L.M., J.P. Harley and Klein. 2002. Microbiology 13th ed. The McGrawHill Companies.New York City.

Sulistiyaningsih. 2008. Identifikasi isolat bakteri penghasil zat antibiotikaa dari cairan kantung tanaman kantong semar (Nepenthes ampullaria, Jack). Laporan Penelitian. Univ. Padjadjaran. Bandung.

Volk, W.A. and M.F. Wheeler. 1993. Mikrobiologi Dasar. Erlangga. Jakarta.

Yogiara. 2004. Analisis komunitas bakteri cairan kantung semar (Nepenthes spp.) menggunakan teknik TerminalRestriction Fragment Length Polymorphism (T-RFLP) dan AmplifiedRibosomal DNA Analysis (ARDRA). Tesis. Instistut Pertanian Bogor.Bogor. 
Vol. 1, No. 1, 2015

Tumbuhan Kantong Semar

Isolasi Bakteri Penghasil Antibiotika Dari Cairan Kantung

Zuhud, E.A.M., W.P. Rahayu, C.H. Wijaya dan P.P. Sari. 2001. Aktifitas antimikroba ekstrak kedaung (Parkiaroxburghii G. Don) terhadap bakteri patogen. Teknol dan Industri Pangan. 12(1);1-7. 